\title{
Properties of Solid Fuel Briquettes Produced from Rejected Material of Tea Waste
}

\author{
YINGCHAO LINa, TING WANGb, ${ }^{\text {* }}$ YUENING LIc and HONGJUN MAO ${ }^{d}$ \\ Centre for Urban Transport Emission Research, College of Environmental Science and Engineering, \\ Nankai University, Tianjin 300071, China \\ adei@nankai.edu.cn, ${ }^{b}$ wangting@nankai.edu.cn, \\ cyueninglee@yeah.net, ${ }^{d h}$ ongjunmao@nankai.edu.cn
}

Keywords: biomass, briquetting, tea waste, fuel, energy source

Abstract. Tea waste was briquetted at ambient temperature for 5 minutes under barometric pressure. The total moisture, ash content, volatiles content, fixed carbon content, sulfur content and high calorific value of the briquettes were investigated. The tea waste briquettes had a high calorific value of $11.23 \mathrm{MJ} / \mathrm{kg}$, which was comparable to that of median coal.

\section{Introduction}

It has been an increasingly interest in biomass technologies recently. The 12th Five-Year Plan of China for the Development of Biomass Energy clearly stipulates the establishment of biomass fuel production, storage, transportation and uses system, and promotes the use of biomass fuel as a central heating source in urban areas and in rural areas as clean cooking and heating fuel ${ }^{[1]}$.

Tea residue refers to tea in the cultivation, processing, processing and circulation of consumption generated by the process of tea biomass as the main body of the waste, is the agricultural solid waste is an important component. According to statistics, the output of the world's tea in 2015 the world's 502.6 million tons, of which China's tea production of 209.2 million tons ${ }^{[2]}$, these tea production and consumption process will produce a lot of tea residue, and with the increasing demands of tea products such as tea bags, tea drinks and tea polyphenols and other health products meeting the people living habits, deep processing tea had produced a large number of tea waste.

However, the disposal of tea residue is becoming an ecological and environmental problem. The disposal of tea residue not only caused environmental pollution, but also a huge waste of biomass resources. In recent years, how to develop and utilize waste of tea residue has become a hotspot in recent years. Therefore, how to make use of tea residue to prepare biomass fuel, so as to utilize biomass waste as well as to develop a new environment-friendly energy material, is a technical problem which researchers trying to solve.

Biomass energy production technology offers the hope of increasing economic efficiency and energy independence in the United States and other countries ${ }^{[3]}$. The US biomass power industry has grown from less than 200 megawatts in 1979 to more than 6,000 megawatts in 1990, The installed capacity is expected to grow to 22,000 megawatts by $2010^{[4]}$.

Due to the rapid growth of population and industry, Turkey's increased demand for and use of energy has raised concerns about the economic and environmental impact of national energy-based generation ${ }^{[5]}$. Agricultural residues are an important source of biomass. The burning rate of the pulverized biomass fuel is significantly higher than other combustion rates. The pulverized biomass fuel may be combusted in a flame in the same manner as oil or gas at the same high power output ${ }^{[6]}$. The desired burning rate is achieved only by crushing the pulverized biomass material.

Due to the very easy flammability, the waste biomass is not suitable for direct use in domestic use. In general, because of the high density, clumped waste biomass may be difficult to ignite due to low porosity. As a result, as the bulk density increases, the ignitability decreases ${ }^{[7]}$.

Briquettes can be considered a good idea for evaluating low-grade combustible materials obtained from different biomass sources. In previous studies, considerable attention has been focused on lignocelluloses' waste, crushed plastics and other combustible waste compacts ${ }^{[7-11]}$. 
It is believed that the protein and longer cellulosic fiber content of the combustible waste is primarily responsible for binding and stabilization ${ }^{[7-8]}$. Waste from the tea plant contains $10.1-10.5 \%$ of the production of black tea ${ }^{[12]}$. The treatment of this waste in the field has been achieved by burning or farming back into the soil. Tea waste stores the solar energy obtained during the growing season and represents an annual renewable energy source, and the effect of the briquetting temperature and time on the briquette density of tea waste were determined ${ }^{[13]}$.

In this study, tea waste was briquetted at ambient temperature for 5 minutes under barometric pressure to establish a novel biomass fuel. Moreover, the total moisture, ash content, volatiles content, fixed carbon content, sulfur content and high calorific value of the briquettes were investigated.

\section{Methods and materials}

Samples of tea waste were collected and air-dried. The air-dried samples were ground in order to pass through a $1.0 \mathrm{~mm}$ aperture screen. The samples of tea waste were briquetted at ambient temperatures for 5 minutes under barometric pressure. The briquettes obtained were cylindrical in shape. A series of experiments were carried out to determine the effects of different moisture contents of the samples and the compressive strength of the briquettes without binder material. A series of tests were also applied to determine the total moisture, ash content, volatiles content, fixed carbon content, sulfur content and high calorific value of the briquettes.

\section{Results and Discussion}

The tea slag biomass solid forming fuel comprises the following raw materials in percentage by weight: $85 \%$ of tea residue and $15 \%$ of sawdust carbon. The optimal moisture content was $20 \%$. The tea residue and the sawdust carbon are weighed according to the weight, and then uniformly stirred the tea residue and sawdust charcoal extruded through a briquetting machine. The properties of the biomass fuel was listed in Table 1 .

Table1 Properties of Biomass Molding Fuel for Tea Residue

\begin{tabular}{|c|c|c|c|c|c|c|}
\hline Item & $\begin{array}{c}\text { Total } \\
\text { moisture } \\
(\%)\end{array}$ & $\begin{array}{c}\text { Ash } \\
(\%)\end{array}$ & $\begin{array}{c}\text { Volatiles } \\
(\%)\end{array}$ & $\begin{array}{c}\text { Fixed } \\
\text { carbon } \\
(\%)\end{array}$ & $\begin{array}{c}\text { Sulfur } \\
\text { content } \\
(\%)\end{array}$ & $\begin{array}{c}\text { High } \\
\text { calorific } \\
\text { value } \\
(\mathrm{MJ} / \mathrm{kg})\end{array}$ \\
\hline $\begin{array}{c}\text { Tea residue biomass } \\
\text { molding fuel }\end{array}$ & 16.6 & 29.39 & 48.55 & 5.46 & 0.42 & 11.23 \\
\hline
\end{tabular}

The burning of the sawdust charcoal is not easy to catch fire, the tea residue burns quicker, the sawdust charcoal burns a longer time, the two are just in good complement with each other, and the mixture of the molding fuel in the combustion process in the tea residue priority on fire, sawdust charcoal after the fire, so the formation of fuel just formed a honeycomb, so that in the furnace combustion process, the increase in oxygen content and combustion more fully. The tea waste fuel has appropriate moisture and a high calorific value of $11.23 \mathrm{MJ} / \mathrm{kg}$, which was comparable to that of median coal. Thus, this study established a novel fuel of biomass waste.

\section{Conclusion}

This study indicated that tea waste could be used as partial binder materials. A series of experiments were carried out to determine the effects of different moisture contents of the samples and the compressive strength of the briquettes without binder material. For briquette quality control, a series of tests were also applied to determine the total moisture, ash content, volatiles content, fixed carbon content, sulfur content and high calorific value of the briquettes. . The tea waste fuel has 
appropriate moisture and a high calorific value of $11.23 \mathrm{MJ} / \mathrm{kg}$, which was comparable to that of median coal. Thus, this study established a novel fuel of biomass waste.

\section{Acknowledgements}

This work was financially supported by Natural Science Foundation of Tianjin (15JCQNJC15200) and Key Technologies R \& D Program of Tianjin (16YFZCSF00410).

\section{References}

[1] Zhou X Q. Research on Scientific Development of Power System in the 12th Five-Year Plan of China[J]. Power System \& Clean Energy, 2009.

[2] Yin B, Zhang X, Feng H. Research on current situation and development strategy of tea machinery in Rizhao City of Shandong Province[J]. Journal of Chinese Agricultural Mechanization, 2016.

[3] Cantor R A, Rizy C G. Review article. Biomass energy: exploring the risks of commercialization in the United States of America.[J]. Bioresource Technology, 1991, 35(1):1-13.

[4] Bain R L. Electricity from biomass in the United States: Status and future direction[J]. Bioresource Technology, 1993, 46(1):86-93.

[5] Ergudenler,A,and A.Isigigur. Agricultural residues as a potential resource for environmentally sustainable electric power generation in Turkey[J]. Renewable Energy, 1994, 5(s 5-8):204.

[6] Marks J. Wood powder: an upgraded wood fuel. [J]. Forest Products Journal, 1992, 42(9):52-56.

[7] Richards S R. Physical testing of fuel briquettes[J]. Fuel Processing Technology, 1990, 25(2):89-100.

[8] Smith I E, Probert S D, Stokes R E, et al. The briquetting of wheat straw[J]. Journal of Agricultural Engineering Research, 1977, 22(2):105-111.

[9] Richards S, Mills R. Smokeless Fuels from Waste Materials[C]// Institution of Chemical Engineers in Australia, 1978.

[10] Grover P D, Mishra S K. BIOMASS BRIQUETTING: TECHNOLOGY AND PRACTICES[J]. Tourniquet Manual - Principles \& Practice, 1996.

[11] Chen L, Xing L, Han L. Renewable energy from agro-residues in China: Solid biofuels and biomass briquetting technology[J]. Renewable \& Sustainable Energy Reviews, 2009, 13(9):2689-2695.

[12] Ayhan Demirbaş, Atila Çaglar, Alipaşa Ayas, et al. Supercritical and Catalytic Fluid Extractions of Tea Waste[J]. Fuel Science \& Technology International, 1996, 14(3):395-404.

[13] Ayhan Demirbas. Evaluation of Biomass Materials as Energy Sources: Upgrading of Tea Waste by Briquetting Process[J]. Energy Sources, 2010, 21(3):215-220. 